\title{
Erratum to: Investigation of the changes of biophysical/mechanical characteristics of differentiating preosteoblasts in vitro
}

\author{
Ramesh Subbiah ${ }^{1,2}$, Muhammad Suhaeri ${ }^{1,2}$, Mintai Peter Hwang ${ }^{1}$, Woojun Kim ${ }^{1,2}$ and Kwideok Park ${ }^{1,2^{*}}$
}

In the original version of this article [1], there were three errors:

- In the description of the test for cell viability, " $4 \mu \mathrm{M}$ ethidium bromide" should be replaced by " $4 \mu \mathrm{M}$ ethidium homodimer-1 (EthD-1)".

- In the Results and discussion section, the sentence "The surface morphology of gelatin matrix is visualized using AFM and SEM, respectively (Fig. 1b and c)" should read "The surface morphology of gelatin matrix is visualized using SEM and AFM, respectively (Fig. 1b and c)."

- In the Results and discussion section, the sentence "AFM images also depicted a relatively smooth gelatin surface with an RMS Rq of $155.6 \pm 18 \mathrm{~nm}$ (Fig. 1d)" should read "AFM images also depicted a relatively smooth gelatin surface with an RMS Rq of $155.6 \pm 12.3 \mathrm{~nm}$ (Fig. 1d)".

Received: 15 February 2016 Accepted: 15 February 2016

Published online: 19 February 2016

\section{Reference}

1. Subbiah R, Suhaeri M, Hwang MP, Kim W, Park K. Investigation of the changes of biophysical/mechanical characteristics of differentiating preosteoblasts in vitro. Biomater Res. 2015;19:24.

\footnotetext{
* Correspondence: kpark@kistre.kr

${ }^{1}$ Center for Biomaterials, Korea Institute of Science and Technology (KIST), Hwarangno 14-gil 5, Seongbuk-gu, Seoul 136-791, Korea

${ }^{2}$ Department of Biomedical Engineering, Korea University of Science and Technology (UST), Daejon 305-350, Korea
}

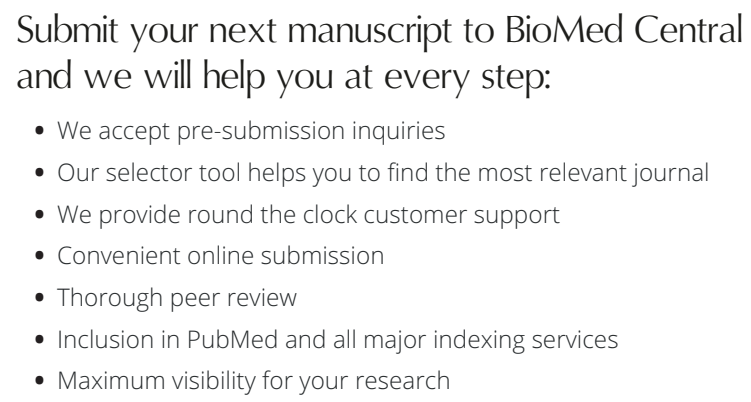

Submit your next manuscript to BioMed Central and we will help you at every step:

- We accept pre-submission inquiries

- Our selector tool helps you to find the most relevant journal

- We provide round the clock customer support

- Convenient online submission

- Thorough peer review

- Inclusion in PubMed and all major indexing services

- Maximum visibility for your research

Submit your manuscript at

www.biomedcentral.com/submit 